\title{
Anticancer effect of deoxypodophyllotoxin induces apoptosis of human prostate cancer cells
}

\author{
SHENG HU, QIANG ZHOU, WAN-RUI WU, YI-XING DUAN, ZHI-YONG GAO, YUAN-WEI LI and QIANG LU \\ Department of Urology, Hunan Provincial People's Hospital, Changsha, Hunan 410005, P.R. China
}

Received April 24, 2015; Accepted June 17, 2016

DOI: $10.3892 / 01.2016 .4943$

\begin{abstract}
Deoxypodophyllotoxin (DPPT) is extracted and separated from citrus-related plants, including Podophyllum (P.) peltatum, P. pleianthum, P. emodi (also called P. hexandrum) and Diphylleia grayi. DPPT has significant antitumor and antiviral activity. However, due to its strong toxicity and side effects, its use is limited in practical applications. The in vitro antitumor efficacy of DPPT on human prostate cancer $(\mathrm{PCa})$ cells remains to be determined. The present study investigated the anticancer effect of DPPT on human PCa cells and its potential mechanism. The data revealed that DPPT markedly reduced cell proliferation and activated the caspase-3 expression level by an increase in apoptotic cell death in DU-145 cells. In addition, treatment with DPPT markedly downregulated the levels of phosphorylated Akt and activated the p53/B-cell lymphoma 2 associated $\mathrm{X}$ protein (Bax)/phosphatase and tensin homolog (PTEN) signaling pathway in DU-145 cells, suggesting that caspase-mediated pathways were involved in DPPT-induced apoptosis. The present study suggested the role of DPPT as a novel chemotherapeutic drug for human $\mathrm{PCa}$, which may function through the Akt/p53/Bax/PTEN signaling pathway.
\end{abstract}

\section{Introduction}

The prostate is the biggest subsidiary gonad organ in the male urogenital system, which is located in the male pelvic cavity and generally has a cone, chestnut-like shape (1). The prostate is situated between the bladder neck and the urogenital diaphragm, being its specific location below the pubic bone, under the bladder, on the upper urogenital diaphragm and before the rectum (2). The normal size of the prostate is as follows: The upper transverse diameter measures $\sim 4 \mathrm{~cm}$, the vertical diameter measures $\sim 3 \mathrm{~cm}$ and the antero-posterior diameter

Correspondence to: Mr. Qiang Zhou, Department of Urology, Hunan Provincial People's Hospital, 61 Liberation West Road, Changsha, Hunan 410005, P.R. China

E-mail: qzhout87@163.com

Key words: deoxypodophyllotoxin, human prostate cancer, apoptosis, Akt/p53/Bax/PTEN measures $\sim 2 \mathrm{~cm}$ (3). Its surface comprises a thin layer of fiber muscular tissue called the prostate capsule, which is the outer sheath of the prostate (3). Morphologically, the prostate can be divided into three zones: The central zone, the peripheral zone and the transition zone (4). The production of prostate fluid is the main physiological function of the prostate, and a variety of enzymes and small molecular components in the prostate fluid are necessary to maintain normal sperm activity (4). The transitional zone is usually associated with hyperplasia of the prostate, while prostate cancer $(\mathrm{PCa})$, the most popular malignant disease of the prostate, most commonly occurs in the peripheral zone (5). $\mathrm{PCa}$ is one of the most common tumors of the genitourinary system, and causes serious damage to men's health (2).

$\mathrm{PCa}$ is the most common malignant tumor in the male reproductive system (1). At present, $\mathrm{PCa}$ is acknowledged as one of the most important medical problems affecting old men (1). PCa is one of the most common solid tumors in Europe and the USA, and the number of cases of PCa has exceeded the number of lung and colorectal cancer cases, thus becoming the first type of tumor affecting men's health (3). According to the World Health Organization International Cancer Research Center GLOBOCAN 2008 estimates (6), there were $\sim 900,000$ new global PCa cases in 2008, with PCa incidence ranking in second place, behind lung cancer (7). The number of newly diagnosed $\mathrm{PCa}$ patients increased by 186,320 cases in the USA in 2008, and 290,000 patients succumbed to PCa (8). In Europe, the PCa rates increased $\leq 214 / 10$ (males) in 2008, with 2.6 million new cases being diagnosed each year (9). In China, the incidence of PCa is currently far lower than that in Europe, USA and other Western countries, and its morbidity and mortality rates are also far lower than the world average rates, being the global standardized incidence and the global standardized mortality rate $27.9 / 1,000,000$ and $7.4 / 1,000,000$, respectively, vs. 83.8/100,000 and 9.7/100,000 reported in the USA and other developed countries (8). However, with the increase in life expectancy, the westernization of the diet and the improvement in diagnostic technology, the morbidity and mortality rates of $\mathrm{PCa}$ are in clearly rising in China, particularly in patients with clinical stage $\mathrm{T} 1$ and $\mathrm{T} 2$, for whom a significant increase in detection rate has been reported $(7,10)$.

Deoxypodophyllotox in (DPPT) is extracted and separated from citrus-related plants, including Podophyllum (P.) peltatum, P. pleianthum, P. emodi (also 
known as $P$. hexandrum) and Diphylleia grayi with good antitumor activity (11). Due to the advantages of DPPT in terms of its small molecular weight and high activity, DPPT is expected to become a new type of high-efficient antitumor drug, whose research and development may provide a new road for antineoplastic drugs (12). The present study aimed to investigate the anticancer effect of DPPT on the induction of apoptosis in human PCa cells, and to further characterize its mechanism.

\section{Materials and methods}

Materials. The RPMI-1640 medium and fetal bovine serum (FBS) were obtained from Gibco (Thermo Fisher Scientific, Inc., Waltham, MA, USA), while 3-(4,5-dimethylthiazol-2-yl)-2,5-diphenyltetrazolium bromide (MTT) was obtained from Sigma-Aldrich (St. Louis, MO, USA). DPPT was purchased from the Medicinal Chemical Institute of China Pharmaceutical University (Nanjing, China). Dimethyl sulfoxide (DMSO) was purchased from Invitrogen (Thermo Fisher Scientific, Inc.). Annexin V-FITC/PI Apoptosis Detection kit was purchased from BestBio. Co. Ltd. (Shanghai, China).

Cell culture. The human PCa cell line DU-145 was obtained from the American Type Culture Collection (Manassas, VA, USA), and was cultured in RPMI-1640 and 10\% FBS, supplemented with $100 \mathrm{U} / \mathrm{ml}$ penicillin and $100 \mu \mathrm{g} / \mathrm{ml}$ streptomycin, at $37^{\circ} \mathrm{C}$ and $5 \% \mathrm{CO}_{2}$ in a humidified atmosphere.

Cell proliferation analysis. The anticancer effectiveness of DPPT on the cell viability of PCa cells was measured by MTT assay. DU-145 cells were plated into 96-well plates at a density of $1.5-3 \times 10^{3}$ cells/well and then treated with DPPT $(0,50,75$ and $100 \mathrm{nM})$ for 12,24 and $48 \mathrm{~h}$. Next, $20 \mu \mathrm{l}$ MTT $(5 \mathrm{mg} / \mathrm{ml})$ was added into each well, and incubated for $4 \mathrm{~h}$ at $37^{\circ} \mathrm{C}$ and $5 \% \mathrm{CO}_{2}$ in a humidified atmosphere. After treatment for $4 \mathrm{~h}$, the medium was removed, and $150 \mu \mathrm{l}$ DMSO was added to each well and agitated for $20 \mathrm{~min}$. The optical density was measured at $490 \mathrm{~nm}$ using a microplate reader (BioTek Instruments, Inc., Winooski, VT, USA).

Apoptosis detection. The anticancer effectiveness of DPPT on the apoptosis of PCa cells was measured by Annexin V-fluorescein isothiocyanate (FITC)/propidium iodide (PI) assay according to the manufacturer's protocol (BestBio. Co. Ltd.). DU-145 cells were plated into 6-well plates at a density of $1-2 \times 10^{6}$ cells/well and then treated with DPPT $(0,50,75$ and $100 \mathrm{nM})$ for $24 \mathrm{~h}$. Flow cytometry (FACSCalibur ${ }^{\mathrm{TM}}$; BD Biosciences, Franklin Lakes, NJ, USA) was used to measure cell apoptosis of DU-145 cells using CellQuest Pro software (BD Biosciences).

Caspase-3 activity assay. The anticancer effectiveness of DPPT on the apoptosis of PCa cells was measured by Annexin V-FITC/PI assay according to the manufacturer's protocol (BestBio. Co. Ltd.). DU-145 cells were plated into 6 -well plates at a density of $1-2 \times 10^{6}$ cells/well and then treated with DPPT $(0,50,75$ and $100 \mathrm{nM})$ for $24 \mathrm{~h}$. The proteins were extracted from cellular lysates dissolved with radioimmunoprecipitation assay buffer, and the protein concentrations were determined with a Protein Assay kit (Bio-Rad Laboratories, Inc., Hercules, CA, USA). Equivalent amounts of proteins (10-20 $\mu \mathrm{g})$ were incubated with $\mathrm{N}$-acet yl-Asp-Glu-Val-Asp-p-nitroaniline for $12 \mathrm{~h}$ and measured at $405 \mathrm{~nm}$ with a microplate reader (Safire2 ${ }^{\mathrm{TM}}$; Tecan; Thermo Fisher Scientific, Inc.).

Western blot analysis. DU-145 cells were plated into 6-well plates at a density of $1-2 \times 10^{6}$ cells/well and then treated with DPPT $(0,50,75$ and $100 \mathrm{nM})$ for $24 \mathrm{~h}$. The proteins were extracted from cellular lysates dissolved with buffer, and the protein concentrations were determined with a Protein Assay kit (Bio-Rad Laboratories, Inc.). Equivalent amounts of proteins $(10-20 \mu \mathrm{g})$ were separated by $8-12 \%$ sodium dodecyl sulfate-polyacrylamide gel electrophoresis and transferred to nitrocellulose membranes (EMD Millipore, Billerica, MA, USA). The blots were incubated with the following antibodies: Anti-phosphorylated (p)-Akt (1:2,000; catalog no. sc-135650; Santa Cruz Biotechnology, Inc., Dallas, TX, USA), anti-p53 (1:2,000; catalog no. sc-1311-R; Santa Cruz Biotechnology, Inc.), anti-B-cell lymphoma $2(\mathrm{Bcl}-2)$ associated $\mathrm{X}$ protein (Bax) (1:1,000; catalog no. sc-783; Santa Cruz Biotechnology, Inc.), anti-phosphatase and tensin homolog (PTEN) (1:1,500; catalog no. sc-9145; Santa Cruz Biotechnology, Inc.) and anti- $\beta$-actin $(1: 1,000$; catalog no. sc-130656; Santa Cruz Biotechnology, Inc.) at $4{ }^{\circ} \mathrm{C}$ overnight. Then, the blots were washed with Tris-buffered saline with Tween-20 (TBST) and incubated with the appropriate secondary antibody (1:5,000; catalog no. A0208; Beyotime Institute of Biotechnology, Haimen, China) at room temperature for $2 \mathrm{~h}$, prior to be developed with enhanced chemiluminescence western blot detection reagents (catalog no. P0018A; Beyotime Institute of Biotechnology).

Statistical analysis. All data are expressed as the mean \pm standard deviation. SPSS 17.0 software (SPSS, Inc., Chicago, IL, USA) was used for statistical analyses, including one-way analysis of variance and Student's $t$-test. $\mathrm{P}<0.05$ was considered to indicate a statistically significant difference.

\section{Results}

Anticancer effect of DPPT reduces cell viability of human PCa cells. The chemical structure of DPPT is shown in Fig. 1. To determine the anticancer effect of DPPT in terms of reducing the cell viability of human PCa cells, DU-145 cells were treated with DPPT $(0,50,75$ and $100 \mathrm{nM})$ for 12,24 and $48 \mathrm{~h}$, and cell proliferation was determined using MTT assay. Cell proliferation of DU-145 cells was effectively inhibited by treatment with DPPT in a dose- and time-dependent manner (Fig. 2).

Anticancer effect of DPPT induces cell apoptosis of human $P C a$ cells. To explore the anticancer effect of DPPT in terms of inducing cell apoptosis of human PCa cells, DU-145 cells were treated with DPPT $(0,50,75$ and $100 \mathrm{nM})$ for 12,24 and $48 \mathrm{~h}$, and cell proliferation was determined by Annexin V-FITC/PI assay. As shown in Fig. 3, the apoptosis of DU-145 cells was induced by DPPT treatment in a dose-dependent manner (Fig. 3). 


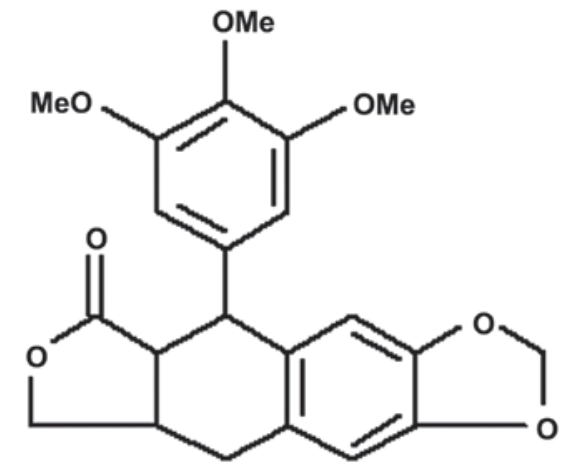

Figure 1. Chemical structure of deoxypodophyllotoxin.

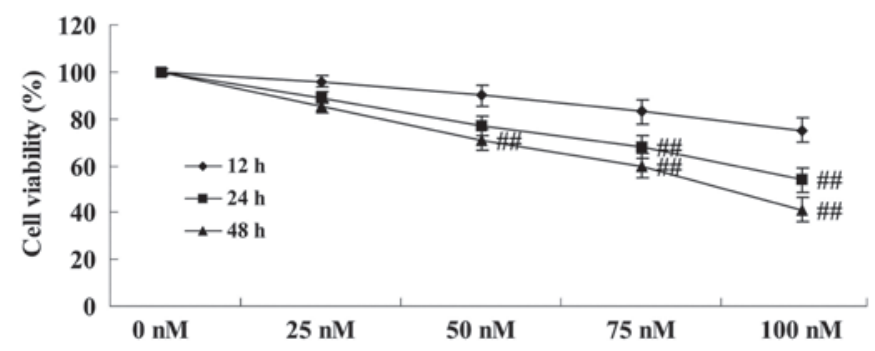

Figure 2. Anticancer effect of DPPT reduces cell viability of human prostate cancer cells. ${ }^{\# \prime} \mathrm{P}<0.01$ vs. 0 nM DPPT-treated group. DPPT, deoxypodophyllotoxin.

Anticancer effect of DPPT induces caspase-3 activity of human PCa cells. To explore the mechanism of DPPT by which it induces cell apoptosis in human PCa cells, the caspase-3 activity of DU-145 cells was evaluated following DPPT treatment. As expected, DPPT-treated cells exhibited a significant increase in caspase-3 activity compared with untreated cells in a dose-dependent manner (Fig. 4).

Anticancer effect of DPPT reduces p-Akt protein expression in human PCa cells. Compared with the blank control, the p-Akt/Akt rate was significantly inhibited in DU-145 cells treated with DPPT in a dose-dependent manner (Fig. 5).

Anticancer effect of DPPT induces p53 protein expression in human PCa cells. Treatment with DPPT (50 or $100 \mathrm{nM})$ for $24 \mathrm{~h}$ resulted in an increase in $\mathrm{p} 53$ protein expression in DU-145 cells compared with untreated cells (Fig. 6). This effect was also dose-dependent (Fig. 5).

Anticancer effect of DPPT induces Bax protein expression in human PCa cells. In order to characterize the anticancer mechanism of DPPT against DU-145 cells, the effects of DPPT on Bax protein expression were examined. Bax protein expression was markedly induced in DPPT-treated DU-145 cells compared with the blank control (Fig. 7).

Anticancer effect of DPPT reduces PTEN protein expression in human PCa cells. To further elucidate the mechanism involved in DPPT-mediated apoptosis, the effects of DPPT on PTEN protein expression were examined. Treatment with DPPT resulted in a dose-dependent increase in PTEN protein expression, compared with untreated control cells (Fig. 8).

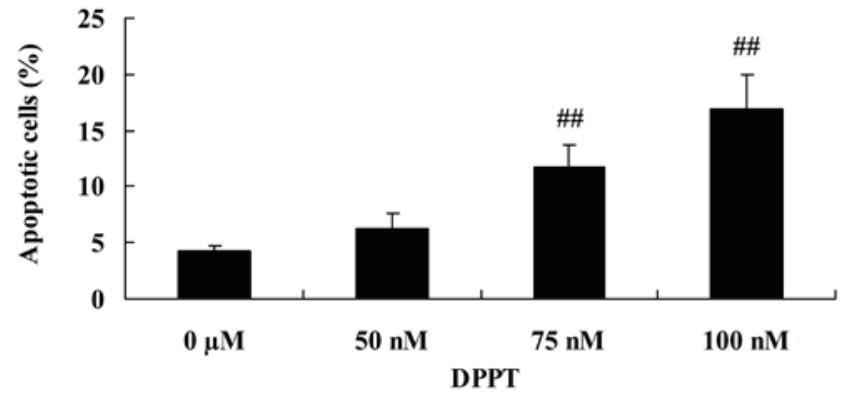

Figure 3. Anticancer effect of DPPT induces cell apoptosis in human prostate cancer cells. ${ }^{\# \#} \mathrm{P}<0.01$ vs. 0 nM DPPT-treated group. DPPT, deoxypodophyllotoxin.

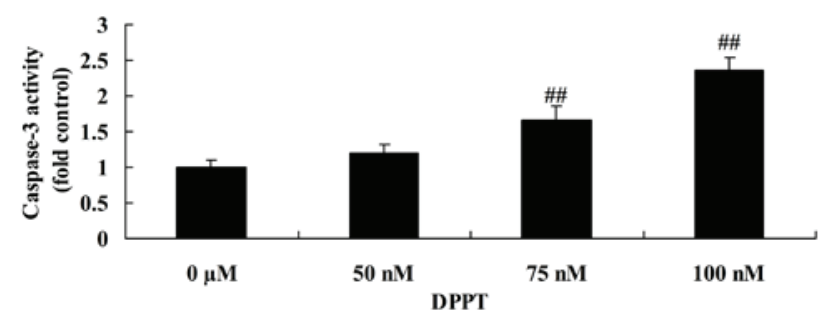

Figure 4. Anticancer effect of DPPT induces caspase-3 activity in human prostate cancer cells. ${ }^{\# \mathrm{P}}<0.01$ vs. 0 nM DPPT-treated group. DPPT, deoxypodophyllotoxin.

\section{Discussion}

In 2008, 34,000 new PCa cases were reported in China (10). The standardized incidence of PCa is $4.3 / 100,000$ of the world population, of which, 140,000 cases succumbed to disease, thus leading to a standardized mortality rate of 1.8/100,000 individuals (10). In Shanghai, the incidence of PCa increased from $12.6 / 100,000$ (males) to 21.8/100,000 during 2000-2005, while in Beijing, the incidence of PCa increased 2.3 times during 1985-1995 (10). In 2004, the incidence of PCa in the Chinese Taiwan and Singapore areas increased 4.8 and 8.5 times, respectively, making the morbidity of $\mathrm{PCa}$ to be considered dangerous (10). Over the next 20 years, the incidence of PCa and the number of associated mortalities in China is expected to increase (13). It is estimated that by 2030 , the average number of PCa cases and associated mortalities per year will increase from 106.4 to $111.4 \%$, and from 4.8 to $5.1 \%$, respectively $(10,13)$. In the present study, DPPT significantly inhibited cell proliferation and cell apoptosis of DU-145 cells in a dose- and time-dependent manner. Several studies indicated that DPPT significantly induced cell apoptosis of HeLa cells (14), breast cancer cells (15) and non-small cell lung cancer cells (16). These results indicated that DPPT may be considered as a drug to target PCa.

The activation of the caspase family plays a key role in the process of cell apoptosis (17). Under normal conditions, caspases are synthesized and stored in the form of inactive precursors, and apoptosis signaling can initiate the caspase cascade (18). Caspase-3 is the main executing factor in the process of apoptosis, since the activation of caspase- 3 has a strong effect on the induction of tumor cell apoptosis. Based on this, caspases inducing caspase-3/8/9 activation participate in the apoptosis program and cause cancer cell apoptosis $(17,19)$. 
A

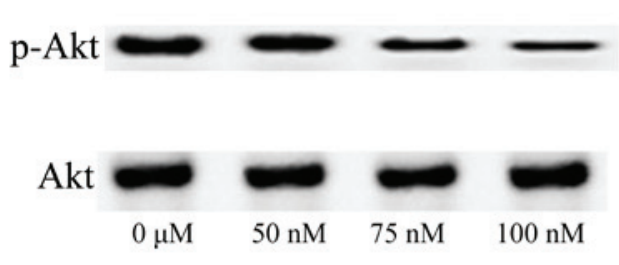

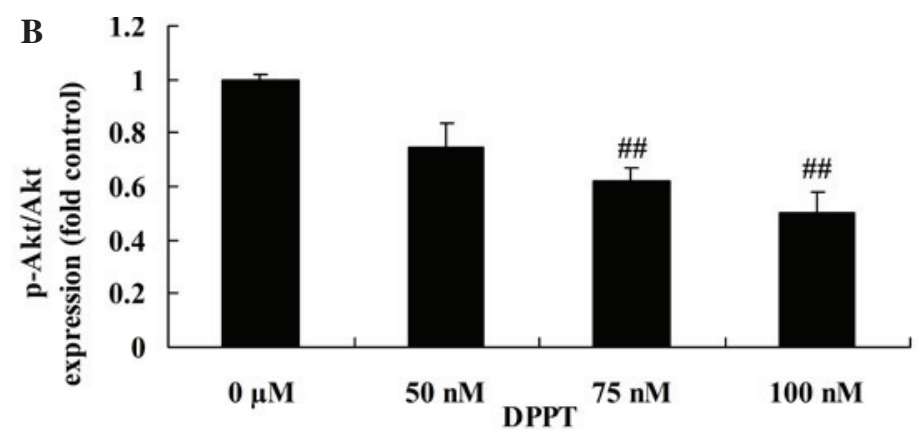

Figure 5. (A) Anticancer effect of DPPT reduces p-Akt protein expression in human prostate cancer cells, as indicated by western blot analysis. (B) Statistical analysis of p-Akt protein expression. ${ }^{\# \#} \mathrm{P}<0.01$ vs. 0 nM DPPT-treated group. DPPT, deoxypodophyllotoxin; p-, phosphorylated.

$\mathbf{A}$

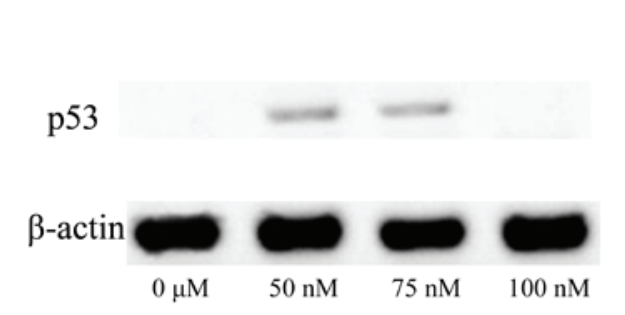

B

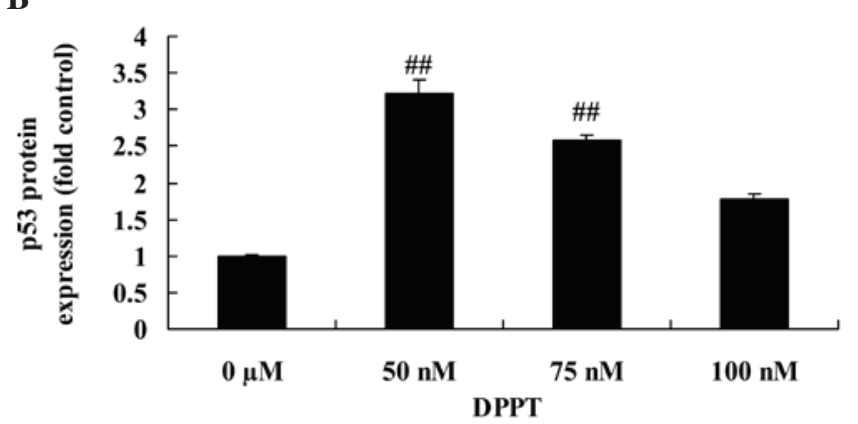

Figure 6. (A) Anticancer effect of DPPT induces p53 protein expression in human prostate cancer cells according to the results of western blot analysis. (B) Statistical analysis of 553 protein expression. ${ }^{\# \#} \mathrm{P}<0.01 \mathrm{vs} .0 \mathrm{nM}$ DPPT-treated group. DPPT, deoxypodophyllotoxin.

A

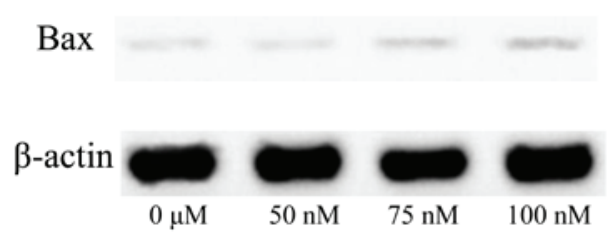

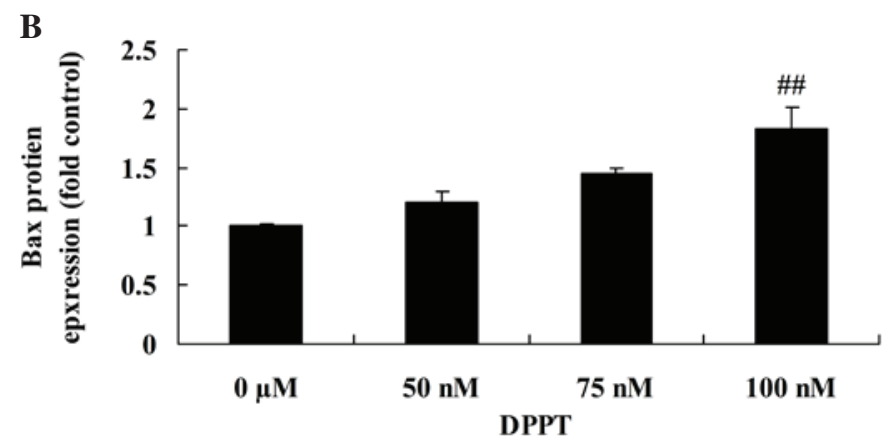

Figure 7. (A) Anticancer effect of DPPT induces Bax protein expression in human prostate cancer cells, as determined by western blotting. (B) Statistical analysis of Bax protein expression. ${ }^{\#} \mathrm{P}<0.01$ vs. $0 \mathrm{nM}$ DPPT-treated group. DPPT, deoxypodophyllotoxin; Bax, B-cell lymphoma 2 associated X protein.

A

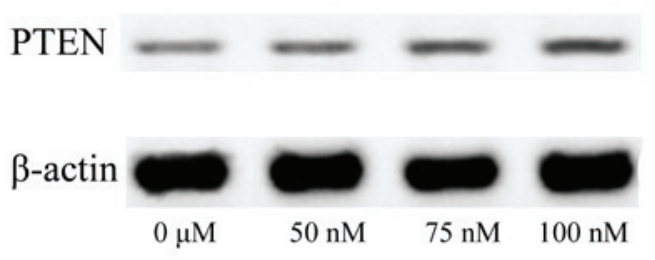

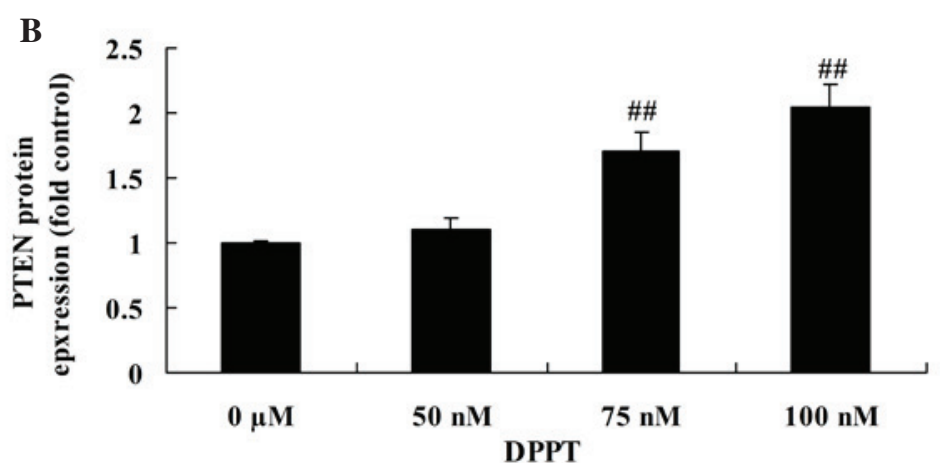

Figure 8. (A) Anticancer effect of DPPT increases PTEN protein expression in human prostate cancer cells, according to the results of western blotting. (B) Statistical analysis of PTEN protein expression. ${ }^{* \prime \prime} \mathrm{P}<0.01$ vs. $0 \mathrm{nM}$ DPPT-treated group. DPPT, deoxypodophyllotoxin; PTEN, phosphatase and tensin homolog. 
In the present study, significant caspase-3 activity was observed in DU-145 cells upon treatment with DPPT. Sang et al (20) reported that DPPT inhibited microtubule formation, and induced caspase-3, Bax and p53 expression. Yong et al (21) indicated that DPPT inhibits tubulin polymerization and activates caspases-3/7 in HeLa human cervix carcinoma cells. The present results demonstrated that DPPT induces caspase- 3 activity, and this pathway appears to be involved in the mechanism of DPPT-induced cell death.

In recent years, studies on molecular biology have demonstrated that cell proliferation and apoptosis are regulated by different genes; therefore, further studies on the regulation of genes at a molecular level will help to increase the understanding of the occurrence and development of PCa (22). Bcl-2, Bax and p53 affect the proliferation, apoptosis, occurrence and development of $\mathrm{PCa}(22,23)$. Among the genes involved in the regulation of cell apoptosis, Bcl-2 is currently recognized as an anti-apoptotic gene (24), which participates in the occurrence of tumors by inhibiting cell apoptosis and prolonging cell survival (25). The present results revealed that treatment with DPPT significantly reduced p-Akt protein expression, and increased p53 and Bax protein expression in DU-145 cells. Shin et al (14) suggested that DPPT induces G2/M cell-cycle arrest through inhibition of Akt and upregulation of the p53 and Bax signaling pathway in HeLa cells. Sang et al (20) demonstrated that DPPT induces cell apoptosis of non-small cell lung cancer A549 cells through p53/cell division cycle 2/Bax signaling.

Previous studies indicated that, in certain tumors such as lung cancer, malignant lymphoma and cancer of the liver, the expression of PTEN in cancerous tissues is significantly higher than that in the corresponding noncancerous tissues. High PTEN expression may be due to the cancer cell proliferation and DNA double chain fractures $(26,27)$. PTEN is one of the key regulation factors in the process of DNA repair and the expression is then increased in order for it to participate in the process of cancer development $(26,27)$. In previous studies, PTEN was tested in PCa and hyperplastic prostate tissues, and it was observed to be mainly expressed in PCa tissues and in the cell nuclei of hyperplastic prostate tissues $(28,29)$. The expression of PTEN in PCa was significantly higher than that in prostate hyperplasia, which indicated that increased PTEN expression levels may be associated with the incidence of PCa $(30,31)$. In the present study, treatment with DPPT significantly promoted PTEN protein expression in DU-145 cells. Shin et al (14) suggested that DPPT induces G2/M cell-cycle arrest through inhibition of Akt and activation of the PTEN signaling pathway in HeLa cells. Consequently, the present results provide the initial evidence that DPPT induces cell apoptosis via the PTEN signaling pathway.

Taken together, the results of the present study indicated that the anticancer effect of DPPT inhibited cell proliferation and induced cell apoptosis in human PCa cells through the Akt/p53/Bax/PTEN signaling pathway. Thus, the present study may provide experimental data for the use of DPPT in the treatment of human PCa.

\section{References}

1. Bashir MN and Malik MA: Case-control study of diet and prostate cancer in a rural population of Faisalabad, Pakistan. Asian Pac J Cancer Prev 16: 2375-2378, 2015.
2. Bettuzzi S, Brausi M, Rizzi F, Castagnetti G, Peracchia G and Corti A: Chemoprevention of human prostate cancer by oral administration of green tea catechins in volunteers with high-grade prostate intraepithelial neoplasia: A preliminary report from a one-year proof-of-principle study. Cancer Res 66: 1234-1240, 2006.

3. Jannini EA, Gravina GL, Morgentaler A, Morales A, Incrocci L and Hellstrom WJ: Is testosterone a friend or a foe of the prostate? J Sex Med 8: 946-955, 2011.

4. Loch T: Prostate cancer diagnostics: Innovative imaging in case of multiple negative biopsies. World J Urol 29: 607-614, 2011.

5. Saunders EJ, Dadaev T, Leongamornlert DA, Jugurnauth-Little S, Tymrakiewicz M, Wiklund F, Al Olama AA, Benlloch S, Neal DE, Hamdy FC, et al: Fine-mapping the HOXB region detects common variants tagging a rare coding allele: Evidence for synthetic association in prostate cancer. PLoS Genet 10: e1004129, 2014.

6. Sverrisson EF, Zens MS, Fei DL, Andrews A, Schned A, Robbins D, Kelsey KT, Li H, DiRenzo J, Karagas MR and Seigne JD: Clinicopathological correlates of Gli1 expression in a population-based cohort of patients with newly diagnosed bladder cancer. Urol Oncol 32: 539-545, 2014.

7. Cullen J, Elsamanoudi S, Brassell SA, Chen Y, Colombo M, Srivastava A and McLeod DG: The burden of prostate cancer in Asian nations. J Carcinog 11: 7, 2012.

8. Center MM, Jemal A, Lortet-Tieulent J, Ward E, Ferlay J, Brawley $\mathrm{O}$ and Bray F: International variation in prostate cancer incidence and mortality rates. Eur Urol 61: 1079-1092, 2012.

9. Tsilidis KK, Papadimitriou N, Capothanassi D, Bamia C, Benetou V, Jenab M, Freisling H, Kee F, Nelen A, O'Doherty MG, et al: Burden of cancer in a large consortium of prospective cohorts in Europe. J Natl Cancer Inst 108: djw127, 2016.

10. Bray F, Jemal A, Grey N, Ferlay J and Forman D: Global cancer transitions according to the Human development index (2008-2030): A population-based study. Lancet Oncol 13: 790-801, 2012.

11. Bianchi E, Caldwell ME and Cole JR: Antitumor agents from Bursera microphylla (Burseraceae) I. Isolation and characterization of deoxypodophyllotoxin. J Pharm Sci 57: 696-697, 1968.

12. Khaled M, Jiang ZZ and Zhang LY: Deoxypodophyllotoxin: A promising therapeutic agent from herbal medicine. J Ethnopharmacol 149: 24-34, 2013.

13. Wu TT and Huang JK: The clinical usefulness of prostate-specific antigen (PSA) level and age-specific PSA reference ranges for detecting prostate cancer in Chinese. Urol Int 72: 208-211, 2004.

14. Shin SY, Yong Y, Kim CG, Lee YH and Lim Y: Deoxypodophyllotoxin induces $\mathrm{G} 2 / \mathrm{M}$ cell cycle arrest and apoptosis in HeLa cells. Cancer Lett 287: 231-239, 2010.

15. Benzina S, Harquail J, Jean S, Beauregard AP, Colquhoun CD, Carroll M, Bos A, Gray CA and Robichaud GA: Deoxypodophyllotoxin isolated from Juniperus communis induces apoptosis in breast cancer cells. Anticancer Agents Med Chem 15: 79-88, 2015.

16. Wu M, Jiang Z, Duan H, Sun L, Zhang S, Chen M, Wang Y, Gao Q, Song Y, Zhu X and Zhang L: Deoxypodophyllotoxin triggers necroptosis in human non-small cell lung cancer NCI-H460 cells. Biomed Pharmacother 67: 701-706, 2013.

17. Fan JH, Feng GG, Huang L, Tang GD, Jiang HX and Xu J: Naofen promotes TNF- $\alpha$-mediated apoptosis of hepatocytes by activating caspase-3 in lipopolysaccharide-treated rats. World $\mathbf{J}$ Gastroenterol 20: 4963-4971, 2014.

18. Yamamoto Y, Koma H, Hiramatsu H, Abe M, Murakami K, Ohya A and Yagami T: Treatment of etoposide combined with 15-deoxy- $\Delta 12,14$-prostaglandin $\mathrm{J} 2$ exerted synergistic antitumor effects against renal cell carcinoma via peroxisome proliferator-activated receptor- $\gamma$-independent pathways. Mol Clin Oncol 2: 292-296, 2014.

19. Carrillo García C, Riedt T, Li J, Dotten M, Brossart P and Janzen V: Simultaneous deletion of p21Cip1/Waf1 and caspase-3 accelerates proliferation and partially rescues the differentiation defects of caspase-3 deficient hematopoietic stem cells. PLoS One 9: e109266, 2014.

20. Sang CY, Xu XH, Qin WW, Liu JF, Hui L and Chen SW: DPMA, a deoxypodophyllotoxin derivative, induces apoptosis and anti-angiogenesis in non-small cell lung cancer A549 cells. Bioorg Med Chem Lett 23: 6650-6655, 2013.

21. Yong Y, Shin SY, Lee YH and Lim Y: Antitumor activity of deoxypodophyllotoxin isolated from Anthriscus sylvestris: Induction of $\mathrm{G} 2 / \mathrm{M}$ cell cycle arrest and caspase-dependent apoptosis. Bioorg Med Chem Lett 19: 4367-4371, 2009. 
22. Lee JH, Cho HD, Jeong IY, Lee MK and Seo KI: Sensitization of tumor necrosis factor-related apoptosis-inducing ligand (TRAIL)-resistant primary prostate cancer cells by isoegomaketone from Perilla frutescens. J Nat Prod 77: 2438-2443, 2014.

23. Smith B, Randle D, Mezencev R, Thomas L, Hinton C and Odero-Marah V: Camalexin-induced apoptosis in prostate cancer cells involves alterations of expression and activity of lysosomal protease cathepsin D. Molecules 19: 3988-4005, 2014

24. Wakabayashi K, Saito H, Ebinuma H, Saito Y, Takagi T, Nakamura M, Umezawa A, Hata J and Ishii $\mathrm{H}$ : Bcl-2 related proteins are dramatically induced at the early stage of differentiation in human liver cancer cells by a histone deacetylase inhibitor projecting an anti-apoptotic role during this period. Oncol Rep 7: 285-288, 2000.

25. Yeh YC, Liu TJ and Lai HC: Shikonin induces apoptosis, necrosis, and premature senescence of human A549 lung cancer cells through Upregulation of p53 Expression. Evid Based Complement Alternat Med 2015: 620383, 2015.

26. Nishimura R, Arima N, Toyoshima S, Ohi Y, Anan K, Sagara Y, Mitsuyama S and Tamura K: Evaluation of PTEN loss and PIK3CA mutations and their correlation with efficacy of trastuzumab treatment in HER2-positive metastatic breast cancer: A retrospective study (KBC-SG 1001). Mol Clin Oncol 1: 47-52, 2013.
27. Jung S, Li C, Jeong D, Lee S, Ohk J, Park M, Han S, Duan J, Kim C, Yang Y, et al: Oncogenic function of p34SEI-1 via NEDD4-1-mediated PTEN ubiquitination/degradation and activation of the PI3K/AKT pathway. Int J Oncol 43: 1587-1595, 2013.

28. Hancox U, Cosulich S, Hanson L, Trigwell C, Lenaghan C, Ellston R, Dry H, Crafter C, Barlaam B, Fitzek M, et al: Inhibition of PI3K $\beta$ signaling with AZD8186 inhibits growth of PTEN-deficient breast and prostate tumors alone and in combination with docetaxel. Mol Cancer Ther 14: 48-58, 2015.

29. Ghalali A, Wiklund F, Zheng H, Stenius U and Högberg J: Atorvastatin prevents ATP-driven invasiveness via P2X7 and EHBP1 signaling in PTEN-expressing prostate cancer cells. Carcinogenesis 35: 1547-1555, 2014.

30. Wu Z, McRoberts KS and Theodorescu D: The role of PTEN in prostate cancer cell tropism to the bone micro-environment. Carcinogenesis 28: 1393-1400, 2007.

31. Schmitz M, Grignard G, Margue C, Dippel W, Capesius C, Mossong J, Nathan M, Giacchi S, Scheiden R and Kieffer N: Complete loss of PTEN expression as a possible early prognostic marker for prostate cancer metastasis. Int J Cancer 120: 1284-1292, 2007. 